\title{
KONSEP EKONOMI PADA MASA BANI UMAYYAH, ABBASIYAH DAN TURKI USMANI
}

\author{
Oleh: \\ Nurul Wahida Aprilya (90100118110)
}

Fakultas Ekonomi dan Bisnis Islam UIN Alauddin Makassar e-mail: wahidaprilya@gmail.com

\section{A. Masa Bani Umayyah}

Bani Umayyah merupakan khalifah pertama setelah berakhirnya masa pemerintahan Khulafaurasyidin. Pemerintahan Bani Umayyah berkuasa hampir satu abad (91 tahun) yaitu pada tahun $41 \mathrm{H}$ sampai dengan $132 \mathrm{H}$. Walaupun tidak cukup seabad, masa Bani Umayyah ini telah mengukir sejarah baru, yang dimana terdapat kemajuan dan kesuksesan dalam perluasan wilayah pemerintahan Islam dan juga penduduk yang masuk agama Islam. Bani Umayyah disebut sebagai pemerintahan yang monarki, karna dia telah melahirkan sebuah sistem pemerintahan kerajaan turun temurun (monarchies heredetis). Pada masa pemerintahan Bani Umayyah, terdapat 14 khalifah yang pernah memerintah yaitu :

1. Muawwiyah bin Abi Sufyan (41-60 H / 661-679 M)

2. Yazid bin Muawwiyah (60-64 H / 679-683 M)

3. Muawwiyah bin Yazid (64 H / 683 M)

4. Marwan bin Hakam (64-65 H / 683-684 M)

5. Abdul Malik bin Marwan (65-86 H / 684-705 M)

6. Al-Walid bin Abdul Malik (86-96 H / 705-714 M)

7. Sulaiman bin Abdul Malik (96-99 H / 714-717 M)

8. Umar bin Abdul Aziz (99-101 H / 717-719 M)

9. Yazid bin Abdul Malik (101-105 H / 719-723 M)

10. Hisyam bin Abdul Malik (105-125 H / 723-742 M) 
11. Al-Wahid bin Yazid (125-126 H / 742-743 M)

12. Yazid bin Walid bin Abdul Malik (126 H/ 743 M)

13. Ibrahim bin Walid bin Abdul Malik (126-127 H / 743-744 M)

14. Marwan bin Muhammad (127-132 H / 744-750 M)

Perkembangan ilmu ekonomi pada masa Bani Umayyah tidak begitu menonjol apabila dibandingkan dengan bidang-bidang keilmuan yang lainnya, Namun terdapat beberapa sumbangan pemikiran dari beberapa khalifah Bani Umayyah terhadap kemajuan ekonomi Islam, diantaranya yaitu perbaikan terhadap konsep transaksi saham, murabahah, muzara'ah dan kehadiran kitab al-Kharaj yang ditulis oleh Abu Yusuf yang hidup pada masa kepemerintahan khalifah Hasyim yang membahas tentang kebijakan ekonomi (Dewi indasari, 2017:56). Diantara dari 14 khalifah yang pernah menjadi pemimpin pada masa Bani Umayyah, ada 3 khalifah yang paling menonjol dan mempunyai kebijakan-kebjakan ekonomi yang diterapkan di masanya, yaitu: Muawwiyah bin Abi Sufyan, Abdul Malik bin Marawan dan Umar bin Abdul Aziz.

Pemikiran ekonomi pada masa pemerintahan Muawwiyah bin Abi Sufyan, yaitu: mendirikan departemen pencatatan, mencetak mata uang, menerapkan kebijakan pemberian gaji tetap untuk para tentara, membangun birokrasi seperti fungsi pengumpulan pajak dan administrasi politik (Ali, 1999:266).

Pemikiran ekonomi pada masa pemerintahan Abdul Malik bin Marwan, yaitu Melakukan berbagai pembenahan administrasi pemerintahan dan memberlakukan bahasa arab sebagai bahasa resmi administrasi pemerintahan Islam (Karim, 2006:34). Dan pada masa pemerintahan Abdul Malik, perkembangan pada perdagangan, perekonomian, dan teraturnya pengelolaan pendapatan negara yang didukung oleh keamanan dan ketertiban yang terjamin telah memabawa masyarakatnya pada tingkat kemakmuran. Realisasinya dapat dlihat dari hasil penerimaan pajak di wilayah Syam, yang tercatat 1.730.000 dinar emas dalam setahun (Naila farah, 2014:32). 
Pada masa pemerintahan Umar bin Abdul Aziz, beliau tidak mengambil sepersenpun dari baitul mal termasuk fa'i yang menjadi haknya. Beliau lebih memprioritaskan pembangunan dalam negeri dan juga melakukan berbagai kebijakan-kebijakan untuk melindungi dan menigkatkan taraf hidup masyarakat secara keseluruhan. Kebijakan yang dilakukan yaitu : menghapus pajak terhadap kaum muslim, mengurangi pajak kaum nasrani, membuat aturan takaran dan timbangan, dan membasmi kerja paksa (Dewi Indasari, 2017:59). Khalifah Umar bin Abdul Aziz menerapkan kebijakan ekonomi daerah. Setiap wilayah islam mempunyai wewenang mengelola zakat dan pajak secara sendir-sendiri serta tidak mengharuskan untuk menyerahkan upetinya kepada pemerintah pusat. Dalam bidang pertanian, beliau melarang penjualan tanah garapan agar tidak ada penguasaan lahan. Dalam menetapkan sewa tanah, beliau melarang adanya pungutan sewa terhadap tanah yang tidak subur dan jika tanah itu subur maka pengambilan sewa harus memperhatikan tingkat kesejahteraan hidup petani yang bersangkutan (Ridjaluddin, 2003:52).

\section{B. Masa Bani Abbasiyah}

Bani Abbsiyah muncul setelah berhasil menggulingkan pemerintahan dinasti Bani Umayyah pada tahun $750 \mathrm{H}$. Pendiri dinasti ini adalah keturunan al-Abbas, yaitu paman dari Nabi Muhammad SAE, sehingga khilafah tersebut dinamakan khilafah Abbasiyah. Khalifah yang mendirikan dinasti ini adalah Abdullah al-Saffah bin Muhammad bin Ali bin Abdullah bin Abbas (132-136 H) (Amalia, 2010: 106). Pada masa pemerintahan Abbasiyah, pusat pemerintahan yang diterapkan dari Damaskus ke Baghdad selama kurang lebih lima abad. Pola pemerintahan yang diterapkan pada masa ini berbeda-beda sesuai dengan perubahan politik, sosial dan budaya. Pada masa pemerintahan Bani Abbasiyah, umat islam mencapai puncak kejayaan dan kemajuan diberbagai bidang, dan wilayah kekuasaan juga semakin luas. Dengan wilayah yang luas, maka pemerintahan Abbasiyah menaruh perhatian yang cukup pada masalah-masalah yang berhubungan dengan perekonomian masyarakat (Sirajuddin, 2016:50). 
Pada masa pemerintahan Bani Abbasiyah, ada 5 periode (Fahmi, 2016:31), yaitu:

1. Periode pertama, Dari tahun (132-232 H / 750-847 M), pada periode ini disebut dengan periode pengarus Persia pertama.

2. Periode kedua, dari tahun (232-334 H / 847-945 M), pada periode ini disebut dengan masa pengaruh Turki Pertama.

3. Periode ketiga, dari tahun (334-447 H / 945-1055 M), periode ini disebut dengan masa kekuasaan dinasti Buwaih dalam pemerinthan khalifah Abbasiyah, periode ini disebut juga sebagai masa pengaruh persia kedua.

4. Periode keempat, dari tahun (447-590 H / 1055-1194 M), periode ini disebut dengan masa kekuasaan dinasti Bani Saljuk dalam pemerintahan kahlifah Abbasiyah, periode ini biasa disebut juga dengan masa pengaruh Turki kedua.

5. Periode kelima, dari tahun (590-656 H / 1194-1258 M), periode ini disebut dengan masa khalifah bebas dari pengaruh dinasti lain, tetap kekuasaannya hanya efektif disekitar kota Bagdad.

Pada masa pemerintahan Al-Manshur, dia dikenal sebagai khalifah yang sangat keras, karena khalifah sebelumnya yaitu Al-Saffah menggunakan dana Baitul Mal untuk diberikan kepada para sahabat dan tentara demi untuk memilih dia sebagai penguasa. Hal tersebutlah yang membuat khalifah Al-Manshur ini sangat keras terhadap keuangan negara, dia bahkan mengendalikan harga-harga dan memerintahkan para kepala jabatan pos untuk melaporkan harga dari setiap bahan makanan dan barang lainnya. Khalifah alManshur juga sangat hemat dalam memblanjakan harta Baitul Mal. Ketika beliau wafat kekayaan kas negara telah mencapai 810 dirham. (Hasyimi, 1987:209)

Pada masa pemerintahan Al-Mahdi, perekonomian negara mulai meningkat dengan peningkatan disektor pertanian yang melalui irigasi dan peningkatan hasil pertambangan seperti emas, perak, tembaga dan besi. Untuk lebih meningktakan sektor pertanian, pemerintah menegluarkan kebijakan-kebijakan untuk para petani, seperti peringanan 
hasil pajak hasil bumi, perluasan lahan pertanian disetiap daerah, dan pembangunan berbagai bendungan dan kanal. Untuk meningkatkan sektor perdagangan, pemerintah membuat sumur-sumur untuk membangun tempat-tempat peristirahatan para kafilah dagang, dan mendirikan berbagau armada dagang serta menjaga keamanan pelabuhan dan pantai.

Pada masa pemerintahan Abu Ja'far Al-Mansur, kebijakan ekonomi yang telah ia lakukan adalah: Penertiban administrasi birokrasi, Bersikap keras dalam peneguhan kedudukan keuangan negara, dan Hemat dalam memberlanjakan uang negara.

Pada masa pemerintahan Harun Al-Rasyid, beliau melakukan diservikasi atau penganekaragaman sumber pendapatan negara (pertanian, perdagangan, dll), ia membangun Baitul Mal untk mengurus keuangan negara, dan Harun Al-Rasyid sangat memperhatikan masalah tentang perpajakan. Ia menujuk Abu Yusuf untuk mneyusun sebuah kitab tetang keuangan dan judul kitab tersebut adalah al-Kharaj.

\section{Masa Turki Ustmani}

Setelah berakhirnya masa pemerintahan Abbasiyah dan setelah hancurnya Bagdad ditangan bangsa Mongol, bangsa Turki semakin mempertegas pembangunan kekuasaanya sendiri yaitu: Turki Saljuk dan Turki Usmani. Turki Usmani didirikan setelah hancurnya Turki saljuk yang telah berkuasa selama kurang lebih 250 tahun (Syafik, 1997:52). Masa pemerintahan dinasti Ustmani muncul pada tahun $923 \mathrm{H}$, pada saat transisi dari negara Islam menjadi kekahlifaan Islam, dan terus membela islam sampai pada tahun $1337 \mathrm{H}$. Entogrol adalah pembuka jalan berdirinya Turki Usmani putranya Usman sebagai proklamator Kerajaan Turki Usmani tahun 1300M. Kejayaan kerajaan Islam di Turki berada pada masa Dinasti Utsmani, lebih tepatnya pada masa kepemimpinan Sultan Muhammad Al-fatih pada tahun 1453 M (Asra, 2018:129). 
Kebijakan-kebijakan ekonomi pada masa Turki Ustmani, yaitu: Desentralisasi pengaturan pajak, kebijakan dalam bidang pertanian, dan melakukan efisiensi pengeluaran. 


\section{DAFTAR PUSTAKA}

Amalia, E. (2010). Sejarah Pemikiran Ekonomi Islam. Depok: Gramata.

Asghar, Ali Engineer. (1999). Asal Usul dan Perkembangan Islam. Yogyakarta : Pustaka Pelajar.

Asra, M, Dewi Suci Cahyani Yusuf. (2018). Dinasti Turki Usmani. Jurnal Ushuluddin Adab dan Dakwah, 1(1), 101-130.

Azwar Adiwarman, Karim. (2006). Sejarah Pemikiran Ekonomi Islam, Edisi Ke Tiga. Jakarta : PT. Radja Grafindo Persada.

Farah, N. (2014). Perkembangan ekonomi dan Admistrasi Pada Masa Bani Umyyah dan Bani Abbasiayah. Jurnal Al-Amwal, 6(2), 25-50.

Hasyimi. (1987). Sejarah Kebudayaan Islam. Jakarta : Bulan Bintang.

Indahsari, D. (2017). Perkembangan Pemikiran Ekonomi Islam Pada Masa Bani Umyyah. Jurnal Ilmu Pengetahuan Teknologi \& seni, 9(2), 55-60.

Irfani, F. (2016). Potret Pendidikan Islam di Masa Klasik (Dinasti Abbasiyah dan Umayyah). Fikrah, 7(1), 26-35.

Mughani, Syafik. (1997). Sejarah Kebudayaan Islam di Turki, Cet. I; Jakarta: Logos.

Ridjaluddin. (2003). Pemikiran Ekonomi Islam Abu Ubaid, tk : tp

Sirajuddin, S. (2016). Konsep Pemikiran Ekonomi Al-Ghazali. LaaMaisyir: Jurnal Ekonomi Islam, 3(1). 